\title{
SIMULTANEOUS QUANTITATION OF OLMESARTAN MEDOXOMIL AND AMLODIPINE BESYLATE IN COMBINED TABLETS USING HPLC
}

\author{
SYED SHANAZ QUTAB ${ }^{A}$, SYED NAEEM RAZZAQ ${ }^{A, B}$, MUHAMMAD ASHFAQ ${ }^{B}$, ,ISLAM ULLAH KHAN ${ }^{B}$, \\ AHMAD MAHMOOD MUMTAZC
}

\author{
${ }^{a}$ Schazoo Laboratories (Pvt) Ltd. 45. G.T. Road, Lahore-54000, Pakistan \\ ${ }^{b}$ Department of Chemistry, Government College University, Lahore-54000, Pakistan \\ ${ }^{c}$ University College of Pharmacy, University of the Punjab, Lahore-54000, Pakistan
}

(Received: September 26, 2008 - Accepted: December 4, 2008)

\section{ABSTRACT}

A simple, sensitive and isocratic reverse phase high performance liquid chromatographic (RP-HPLC) method has been developed for the simultaneous determination of olmesartan medoxomil and amlodipine in pharmaceutical tablet formulations. HPLC analysis was carried out using reverse phase isocratic elution with a C18 column and a mobile phase of $0.05 \mathrm{M}$ ammonium acetate $\mathrm{pH} 6.8$ and acetonitrile in the ratio of 40:60, v/v. Detection of the analytes was achieved using UV detector at $239 \mathrm{~nm}$. The retention times of olmesartan medoxomil and amlodipine were 2.50 and 3.94 respectively. Linearity of the method was found to be in the concentration range of $16-112 \mu \mathrm{gml}^{-1}$ for olmesartan medoximil and 4-28 $\mu \mathrm{gml}^{-1}$ for amlodipine. The correlation coefficient value was greater than 0.9999 for both the analytes. The method is suitable for the estimation of both the components simultaneously in pharmaceutical tablet formulations.

Key words: HPLC, acetonitrile, olmesartan, amlodipine

\section{INTRODUCTION}

Olmesartan medoxomil (Fig 1) is a prodrug that hydrolysed to olmesartan during absorption ${ }^{1-4}$. It is an angiotensin II receptor antagonist used for hypertension and is chemically designated as 5-methyl-2-oxo-1,3-dioxolen4-yl)methoxy-4-(1-hydroxy-1-methylethyl)-2-propyl-1- $\{4-[2-($ tetrazol-5-yl)phenyl]phenyl\}methylimidazol-5-carboxylate ${ }^{5-6}$. Olmesartan is also beneficial in animals and is a strong agent to show activity against atherosclerosis, liver disorders and diabetic nephropathy ${ }^{7-9}$.<smiles>CCCc1nc(C(C)(C)O)c(C(=O)OCc2oc(=O)oc2C)n1Cc1ccc(-c2ccccc2-c2nn[nH]n2)cc1</smiles>

Fig.1. Chemical structure of Olmesartan medoxomil

Amlodipine besylate [Fig 2] chemically designated as 2-[(2-aminoethoxy)methyl]-4-(2-chlorophenyl) 1,4-dihydro-6-methyl-3,5-pyridine-dicarboxylic acid-3 ethyl-5 methyl ester, is a calcium channel blocker used to treat hypertension and angina ${ }^{10-11}$. Amlodipine blocks the transmembrane influx of calcium ions into vascular smooth muscle and cardiac muscles ${ }^{12-14}$. It is metabolized in the liver and the metabolites are mostly excreted in urine together with less than $10 \%$ of a dose as unchanged drug ${ }^{15-16}$.<smiles>CCOC(=O)C1=C(COCCN)NC(C)=C(C(=O)OC)C1c1ccccc1Cl</smiles>

Fig.2. Chemical structure of Amlodipine besylate

Several analytical methods have already been developed for the determination of olmesartan and amlodipine either individually or in combination with other drugs ${ }^{17-36}$. According to the information extracted from literature, todate there is not even a single method reported for the simultaneous determination of olmesartan and amlodipine in pharmaceutical formulations.

We describe in this paper a simple, sensitive and validated HPLC method for the simultaneous determination of olmesartan and amlodipine in pharmaceutical formulations. The developed method can be applied successfully to quality control and for other analytical purposes.

\section{EXPERIMENTAL}

\section{Chemicals and Reagents}

Olmesartan medoxomil and amlodipine besylate working standards were kindly gifted by Schazoo Laboratories (Pvt) Ltd, Lahore Pakistan. Combination product containing $40 \mathrm{mg}$ olmesartan and $10 \mathrm{mg}$ amlodipine was purchased from the local market. Acetonitrile (HPLC grade), ammonium acetate and acetic acid glacial (analytical reagent grade) were purchased from M.S Traders Lahore Pakistan (Fluka Origin). Double distilled water, prepared in our laboratory was used throughout the experiment. Mobile phase was filtered using $0.45 \mu$ nylon filters made by Millipore (USA) and was sonicated using PSO 1300 sonicator. Whatmann filter papers No.41 (purchased from the local market) were used in the preparation of sample solution.

\section{Apparatus and chromatographic conditions}

HPLC apparatus consisting of Shimadzu LC-20A system equipped with a model LC-20AT pump, an SPD-20A variable wavelength detector (set at 239 $\mathrm{nm}$ ), a CBM-20A interface module with class LC-20 HPLC software and a Rheodyne injection valve with a $20 \mu \mathrm{L}$ loop was used for development and evaluation of this method. A Teknokroma C18 column $(250 * 4.6 \mathrm{~mm}$, i.d., 5 $\mu \mathrm{m}$ particle size) was selected. The mobile phase was composed of $0.05 \mathrm{M}$ 
ammonium acetate $\mathrm{pH} 6.8 \pm 0.05$ and acetonitrile in the ratio of $40: 60, \mathrm{v} / \mathrm{v}$. An external standard method was used with flow rate of the mobile phase as $1 \mathrm{mlmin}^{-1}$. Peak identity was confirmed by spectrum and retention time comparison and the HPLC system was operated at room temperature (25 \pm $\left.2^{\circ} \mathrm{C}\right)$.

\section{Preparation of standard solution}

An amount of $80 \mathrm{mg}$ of olmesartan medoxomil and $20 \mathrm{mg}$ of amlodipine were weighed and transferred into a $100 \mathrm{ml}$ volumetric flask with $60 \mathrm{ml}$ of mobile phase. The solution was sonicated for 15 minutes to completely dissolve both the components. It was then cooled and the volume was completed up to the mark with mobile phase. $2 \mathrm{ml}$ of the above solution was diluted to $25 \mathrm{ml}$ with mobile phase to obtain a final concentration of $64 \mu \mathrm{gml}^{-1}$ for olmesartan medoxomil and $16 \mu \mathrm{gml}^{-1}$ for amlodipine. The solution was filtered through $0.45 \mu$ nylon filters before analysis.

\section{Preparation of sample solution}

Twenty tablets were accurately weighed and their average weight was calculated. The tablets were ground using pestle and mortar made of china clay to a homogenized powder. A quantity of the powdered tablets equivalent to one tablet was weighed and transferred to a $50 \mathrm{ml}$ volumetric flask. $30 \mathrm{ml}$ mobile phase was added and sonicated for 15 minutes to extract all the drugs from the excipients. The solution was cooled and then filtered using Whatmann filter paper no $41.2 \mathrm{ml}$ of the filtrate was transferred to a $25 \mathrm{ml}$ volumetric flask and diluted to the mark with mobile phase. The final concentration thus achieved 64 $\mu \mathrm{gml}^{-1}$ for olmesartan medoxomil and $16 \mu \mathrm{gml}^{-1}$ for amlodipine.

\section{Linearity}

Linear calibration plots for the proposed method were obtained over the calibration range of 16-112 $\mu \mathrm{gml}^{-1}$ for olmesartan medoxomil $(16,40,64,88$, $\left.112 \mu \mathrm{gml}^{-1}\right)$ and 4-28 $\mathrm{ggml}^{-1}$ for amlodipine $\left(4,10,16,22,28 \mu \mathrm{gml}^{-1}\right)$. Each level was made in triplicate.

\section{Accuracy}

To demonstrate the accuracy of the proposed method recovery studies were employed by the standard addition method. Three levels of solutions were made which corresponds to 50,100 and $150 \%$ of the nominal analytical concentration $\left(64 \mathrm{\mu gml}^{-1}\right.$ for olmesartan medoxomil and $16 \mu \mathrm{gml}^{-1}$ for amlodipine). Each level was made in triplicate.

\section{Selectivity}

To check the selectivity of the proposed method a synthetic mixture of olmesartan medoximil and amlodipine was prepared with commonly occurring ingredients that are present in most tablet formulations. The comparison of its chromatograms with the chromatograms of the standard solution was done along with the percentage recovery of both the analytes. Synthetic mixture containing $40 \mathrm{mg}$ olmesartan medoxomil, $10 \mathrm{mg}$ amlodipine and $30 \mathrm{mg}$ each of starch, lactose, magnesium stearate and avicel, which are present as inactives in the pharmaceutical formulation, were accurately weighed and transferred into $50 \mathrm{ml}$ volumetric flask. The mixture was sonicated for 15 minutes with $30 \mathrm{ml}$ mobile phase and then the volume was completed with mobile phase and filtered. $2 \mathrm{ml}$ of the filtrate was then further diluted to $25 \mathrm{ml}$ to obtain

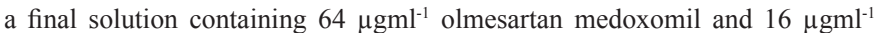
amlodipine.

\section{Robustness}

Robustness of the method was performed by intentionally varying individually, the chromatographic conditions such as composition of the mobile phase, flow rate and $\mathrm{pH}$ of the buffer solution. The chromatographic parameters of each analyte such as retention time, tailing factor, resolution and number of theoretical plates were measured at each changed conditions.

\section{RESULTS AND DISCUSSION}

In this work a simple, sensitive and validated HPLC method has been developed for the simultaneous estimation of olmesartan medoxomil and amlodipine using liquid chromatography with ultraviolet detection. A number of mobile phases were initially attempted to elute both components simultaneously. The main focus was to achieve sharp and gaussian shaped peaks with tailing less than 1.5 and resolution greater than 1.5 . In order to achieve this goal, acetonitrile and water in different proportions were used but no sharp peaks were observed. Ammonium acetate was then added to increase the polarity of the mobile phase. A $0.05 \mathrm{M}$ concentration of ammonium acetate at $\mathrm{pH} 6.8$ with acetonitrile in the ratio of $40: 60, \mathrm{v} / \mathrm{v}$ was strong enough to elute both the components with resolution greater than 5 , theoretical plates greater than 3500 and tailing less than 1.5 for both the components. The best mobile phase composition was then found to be $0.05 \mathrm{M}$ ammonium acetate $\mathrm{pH} 6.8$ and acetonitrile in the ratio of 40:60 (v/v).

The most suitable mobile phase composition was thus found to be $0.05 \mathrm{M}$ ammonium acetate $\mathrm{pH} 6.8$ and acetonitrile in the ratio of 40:60 (v/v). Under the mentioned chromatographic conditions sharp peaks belonging to olmesartan medoxomil and amlodipine were obtained at retention times of 2.50 and 3.94 minutes respectively [Figure 3 and 4 ].

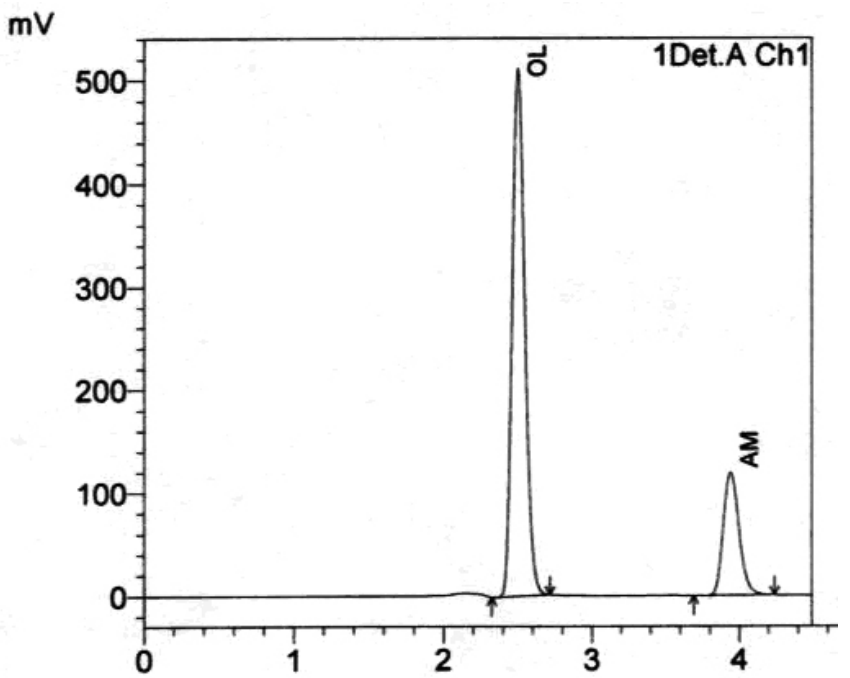

Fig. 3.- Chromatograms of olmesartan medoxomil and amlodipine Reference substance

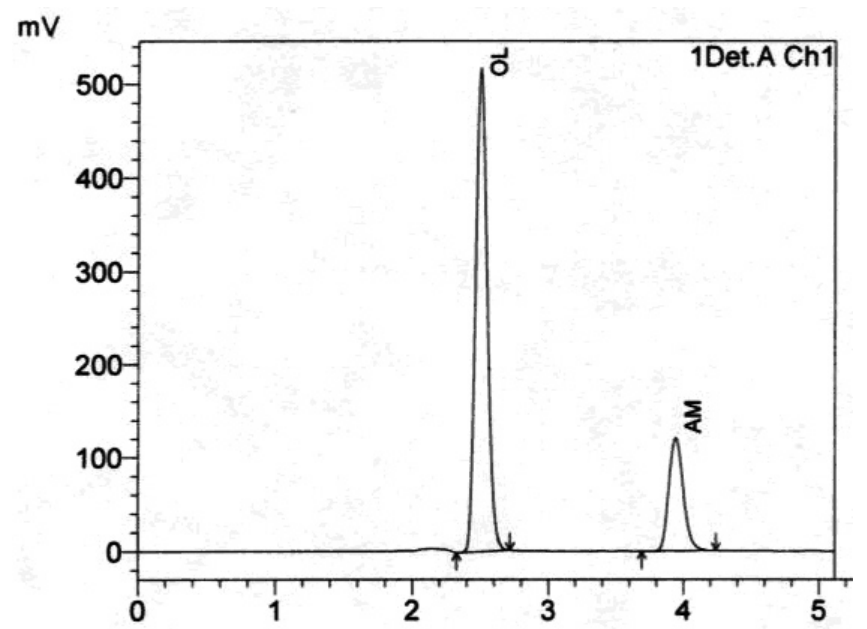

Fig. 4. Chromatograms of olmesartan and amlodipine Tablets

The proposed chromatographic method was validated using ICH guidelines $^{37}$ by performing linearity, limits of detection and quantitation, selectivity, robustness accuracy and repeatability.

Linear calibration plots for the proposed method were obtained by analyzing five solutions in the concentration range of $16-112 \mu \mathrm{gml}^{-1}$ for olmesartan medoxomil and 4-28 $\mathrm{ggml}^{-1}$ for amlodipine. The peak area of drugs was plotted against the corresponding concentration to construct a linear regression equation and to calculate the value of correlation coefficient. The linear regression equation for olmesartan medoxomil was found to be $\mathrm{Y}=$ 48118.5 X - 17557 with correlation coefficient equal to 0.99997 . The linear regression equation for amlodipine was found to be $\mathrm{Y}=56506.5 \mathrm{X}+2235.6$ 
with value of correlation coefficient equal to 0.99999 .

The limit of detection (LOD) and quantification (LOQ) were measured by calculating the minimum level at which the analyte can be readily detected and quantified with accuracy, respectively. In this study, the LOD was found to be 0.08 and $0.12 \mu \mathrm{gml}^{-1}$ for olmesartan medoxomil and amlodipine respectively (signal to noise ratio of 3:1). The LOQ was found to be 0.27 and $0.4 \mu \mathrm{gml}^{-1}$ for olmesartan medoxomil and amlodipine respectively (signal to noise ratio of 10:1).

The accuracy of the method was performed by the standard addition technique. Three levels of solutions were made which correspond to 50,100 and $150 \%$ of the nominal analytical concentration. Each level was made in triplicate. The recovery and relative standard deviation for each of the analytes are given in Table 1. From the recovery studies it is evident that the method is highly accurate and can give excellent results.

Table.1. Accuracy of the proposed HPLC method.

\begin{tabular}{|lccccc|}
\hline Drug & $\begin{array}{c}\text { level } \\
(\%)\end{array}$ & $\begin{array}{c}\text { Concentration } \\
\left(\mu \mathrm{gml}^{-1}\right)\end{array}$ & $\begin{array}{c}\text { Amount recovered } \\
\left(\mu \mathrm{gml}^{-1}\right)\end{array}$ & $\begin{array}{l}\text { \% recovery } \\
\text { \% RSD }\end{array}$ & \\
\hline Olmesartan medoxomil & 50 & 32.0 & 32.32 & 101.0 & 0.73 \\
& 100 & 64.0 & 63.18 & 98.72 & 1.15 \\
& 150 & 96.0 & 95.08 & 99.04 & 0.36 \\
& 50 & 8.0 & 8.12 & 101.50 & 1.32 \\
& 100 & 16.0 & 15.81 & 98.81 & 1.05 \\
& 150 & 24.0 & 24.34 & 101.42 & 0.81 \\
\hline
\end{tabular}

Within-day precision was determined by injecting five standard solutions of three different concentrations on the same day $(n=5)$ and between-day precision was determined by injecting the same solutions for consecutive five days. Relative standard deviation (RSD \%) of the peak area was calculated to represent precision. The results of within-day and between-day precision are presented in Table 2.

Table.2. Precision of the proposed HPLC method.

\begin{tabular}{|lcccccc|}
\hline Compound & Conc. & $\mathrm{n}$ & \multicolumn{2}{l}{ Within-day precision } & \multicolumn{2}{c|}{ Between-day precision } \\
& $\left(\mu \mathrm{gml}^{-1}\right)$ & & Mean & RSD (\%) & Mean & RSD (\%) \\
& & & & & & \\
\hline Olmesartan medoxomil & 16.0 & 5 & 16.13 & 1.22 & 16.06 & 1.45 \\
& 64.0 & 5 & 63.18 & 0.93 & 62.82 & 1.18 \\
& 112.0 & 5 & 110.65 & 0.69 & 110.38 & 0.96 \\
& 4.0 & 5 & 3.95 & 1.39 & 3.96 & 1.48 \\
& 16.0 & 5 & 15.86 & 1.08 & 15.91 & 1.13 \\
& 28.0 & 5 & 28.35 & 0.73 & 28.16 & 1.02 \\
& & & & & & \\
\hline
\end{tabular}

To be considered selective, a method should demonstrate its ability to separate the analyte peaks from the excipients peaks and should not result in co-elution of peaks. The selectivity was tested by making the synthetic mixture of both the analytes with commonly used pharmaceutical excipients. Then its chromatograms were compared with that of standard solution along with the recovery of analytes. No excipients interfered with the main peaks of analytes. The results of recovery study are given in Table 3 , which shows that excipients have no interference with the analyte peaks and the method is found to be highly selective for its intended use.
Table.3. Selectivity of the proposed HPLC method.

\begin{tabular}{|lccccc|}
\hline \multicolumn{3}{|l}{ Olmesartan medoxomil } & \multicolumn{5}{c|}{ Amlodipine } \\
$\begin{array}{l}\text { Added } \\
\left(\mu \mathrm{gml}^{-1}\right)\end{array}$ & Found & \%recovery & Added & Found & \%recovery \\
\hline 64 & 63.59 & 99.36 & 16 & 16.08 & 100.50 \\
64 & 64.13 & 100.20 & 16 & 15.78 & 98.63 \\
64 & 64.83 & 101.30 & 16 & 16.11 & 100.69 \\
64 & 63.25 & 98.83 & 16 & 16.05 & 100.31 \\
Mean \% recovery $=99.92 \%$ & & & Mean \% recovery $=100.03 \%$ \\
RSD & $=1.08 \%$ & & & RSD & $=0.95 \%$ \\
\hline
\end{tabular}

Robustness of the method was performed by slightly varying the chromatographic conditions. The results showed that the slight variations on the chromatographic conditions have negligible effect on the chromatographic parameters showing the method is highly robust for its intended use. The results are given in Table $4 \mathrm{a}$ and $4 \mathrm{~b}$.

Table 4a: Robustness study of Olmesartan medoxomil.

\begin{tabular}{|llll|}
\hline Conditions & RT (min) & Theoretical plate & Tailing \\
\hline Acetonitrile:buffer (60:40) & 2.50 & 3500 & 1.26 \\
Acetonitrile:buffer (62:38) & 2.41 & 3216 & 1.30 \\
Acetonitrile:buffer (58:42) & 2.63 & 3614 & 1.21 \\
Flow rate (1.1 ml/min) & 2.27 & 3164 & 1.32 \\
Flow rate (0.9 ml/min) & 2.78 & 3550 & 1.19 \\
Buffer (pH 6.9) & 2.48 & 3494 & 1.23 \\
Buffer (pH 6.7) & 2.49 & 3465 & 1.23 \\
\hline
\end{tabular}

Table 4b: Robustness study of Amlodipine.

\begin{tabular}{|lllll|}
\hline Conditions & RT (min) & Theoretical plate & Tailing & Resolution \\
\hline Acetonitrile:buffer (60:40) & 3.94 & 5738 & 1.26 & 7.64 \\
Acetonitrile:buffer (62:38) & 3.81 & 5504 & 1.31 & 6.92 \\
Acetonitrile:buffer (58:42) & 4.11 & 5856 & 1.23 & 8.01 \\
Flow rate (1.1 ml/min) & 3.58 & 5201 & 1.29 & 6.54 \\
Flow rate (0.9 ml/min) & 4.38 & 5901 & 1.22 & 7.71 \\
Buffer (pH 6.9) & 3.96 & 5734 & 1.25 & 7.45 \\
Buffer (pH 6.7) & 3.95 & 5768 & 1.25 & 7.52 \\
\hline
\end{tabular}

The application of the method was checked by analyzing the olmesartan medoximil and amlodipine in commercial tablets. The results are given in table 5 which shows high percentage recoveries and low RSD (\%) values. 

tablets.

Table.5. Results of analysis olmesartan medoximil and amlodipine in

\begin{tabular}{|lcclcc|}
\hline Drug & $\mathrm{n}$ & $\begin{array}{c}\text { Amount Claimed } \\
\text { (mg per tablet) }\end{array}$ & $\begin{array}{c}\text { Amount Found } \\
\text { (mg per tablet) }\end{array}$ & $\begin{array}{c}\text { Mean Recovery } \\
(\%)\end{array}$ & $\begin{array}{c}\text { RSD } \\
(\%)\end{array}$ \\
\hline $\begin{array}{lcccc}\text { Olmesartan medoxomil } \\
\text { Amlodipine }\end{array}$ & 5 & 40 & 40.22 & 100.55 & 1.01 \\
& 5 & 10 & 10.08 & 100.80 & 1.27 \\
\hline
\end{tabular}

\section{CONCLUSION}

A simple and accurate reverse phase HPLC method has been described for the simultaneous determination of olmesartan medoxomil and amlodipine. The method was validated by testing its linearity, accuracy, precision, limits of detection and quantitation and selectivity. The run time of less than five minutes allows its application for the routine determination of olmesartan medoximil and amlodipine in pharmaceutical formulations.

\section{REFERENCES}

1. S. Hyogo, D. Hinman, H. Saito, H. Yanagisawa. Ann. Rep. Sankyo Res. Lab., 55, 1 (2003)

2. D. E. Mire, T. N. Silfani, M. K. Pugsley. J. Cardiovasc. Pharm., 46, 585 (2005)

3. N. Kobayashi, I. Fujimori, M. Watanabe, T. Ikeda. Anal. Biochem., 287, 272 (2000)

4. H. Yanagisawa, Y. Amemiya, T. Knazaki, Y. Shimoji, K. Fujimoto, Y. Kitahara, T, Sada, M. Mizuno, M. Ikeda, S. Miyamoto, Y. Furukawa, H. Koike. J. Med. Chem., 39, 323 (1996)

5. M. Mizuno, T, Sada, M. Ikeda, N. Fukuda, M. Miyamoto, H. Yanagisawa, H. Koike. Eur. J. Pharmacol., 285, 181 (1995)

6. M. Takemoto, K. Egashira, H. Tomita, M. Usui, H. Okamoto, A. Kitabatake, H. Shimokawa, K. Sueishi, A. Takeshita. Hypertension., 30, 1621 (1997)

7. E. Pianezzola, V. Bellotti, R. La Croix, B. M. Strolin. J. Chromatgr. B., 574, 170 (1992)

8. K. Igarashi, K. Hotta, F, Kasuya, K. Abe, S. Sakoda. J. Chromatgr. B., 792, 55 (2003)

9. B. A. Kimball, T. J. Deliberto, J. J. Johnston. Anal. Chem., 73, 4972 (2001)

10. M. J. O` Neil, A. Smith, P. E. Heckelman, S. Budavari. The Merck Index, 14th edition, 2006, p 493 and 6149.

11. J. E. Arrowsmith, S. F. Campbell, P.E. Cross, J. K. Stubbs, R. A. Burges, D. G. Gardiner, K. L. Blackburn. J. Med. Chem., 29, 1696 (1986)

12. A. G. Goodman, L. S. Gilman. The pharmacological basis of therapeutics, $8^{\text {th }}$ edition, Paragon Press Oxford, 1990, p. 774.
13. S. C. Sweetman. Martindale the complete drug reference, 34th edition, Pharmaceutical Press, London, 2005, p. 862 and 866.

14. C. Dollery. Therapeutic drugs, 2nd edition, Churchill Livingstone, Uk, 1999, p. 151.

15. D. R. Abernethy. Am. Heart. J., 118, 1100 (1989)

16. P. A. Meredith, H. L. Elliott. Clin. Pharmacokinet., 22, 22 (1992)

17. V. V. Vaidya, S. M. N. Roy, S. M. Yetal, S. S. Joshi, S. A. Parekh. Chromatographia., 67, 147(2008)

18. N. Sultana, M. S, Arayne, S.S. Ali, S. Sajid. Chin. J. Chromatogr., 26(5), 544(2008)

19. S. H. Chen, C. F. Wu, B. M. Chen, Q. Pei, H. Y. Tan, L. Yang, G. P. Yang. Nan Fang Yi Ke Da Xue Xue Bao. 28 (6), 1104(2008)

20. O. Sagirli, A. Onal, S. E. Toker, D. S, Ensoy. Chromatographia., 66, 213 (2007)

21. D. Liu, P. Hua, N. Matsushima, X. Li, L. Li, J. Jiang. J. Chromatogr. B. 856, 190(2007)

22. V. G. Dongre, S. B. Shah, P. P. Karmuse, M. Phadke, V. K. Jadhav. J. Pharm. Biomed. Anal. 46(3), 583 (2008)

23. T. Sivakumar, R. Manavalan, C. Muralidharan, K. Valliappan. J. Sep. Sci. 30(18), 3143 (2007)

24. R. K. Barman, M. A. Islam, M. Ahmed, M. I. Ibne Wahed, R. Islam, A. Khan, M. B. Hossain, B. M. Rahman. Pak. J. Pharm. Sci. 20(4), 274(2007)

25. B. G. Chaudhari, N. M. Patel, P. B. Shah. Chem. Pharm. Bull. 55(2), 241(2007)

26. J. Bhatt, S. Singh, G. Subbaiah, B. Shah, S. Kambli, S. Ameta. Biomed. Chromatogr, 21(2), 169(2007)

27. A. Mohammadi, N. Rezanour, M. D. Ansari, B. F. Ghorbani, M. Hashem, R. B. Walker. J. Chromatogr. B., 846(1), 215(2007)

28. M. D. Malesuik, S. G. Cardoso, L. Bajerski, F. A. Lanzanova. J. AOAC. Int. 89(2), 359(2006)

29. R. V. Nirogi, V. N. Kandikere, K. Mudigonda, M. Shukla, S. Maurya. Biomed. Chromatogr, 20(9), 833(2006)

30. A. Zarghi, S. M. Foroutan, A. Shafaati, A. Khoddam. Farmaco., 60(9), 789(2005)

31. K. R. Naidu, U. N. Kale, M. S. Shingare. J. Pharm. Biomed. Anal., 39, 147 (2005)

32. G. Bahrami, Sh. Mirzaeei. J. Pharm. Biomed. Anal., 36(1), 163(2004)

33. S. Tatar, S. Atmaca. J. Chromatogr. B., 758(2), 305(2001)

34. M. Josefsson, A. L. Zackrisson, B. Norlander. J. Chromatogr. B., 672(2), 310(1995)

35. P. K. Yeung, S. J. Mosher, P. T. Pollak. J. Pharm. Biomed. Anal., 9(7), 565(1991)

36. K. Shimooka, Y. Sawada, H. Tatematsu. J. Pharm. Biomed. Anal., 7(11), 1267 (1989)

37. ICH (Q2B) (1996) Note for guidance on validation of analytical procedures: methodology. International conference on Harmonisation, IFPMA, Geneva. 